\title{
THE EFFECT OF FACTORS ASSOCIATED WITH THE MALE ON NUMBERS OF OVULATIONS, UTERINE WEIGHT AND PITUITARY LH CONTENT IN THE RAT
}

\author{
K. J. COOPER AND N. B. HAYNES \\ Department of Physiology and Environmental Studies, \\ University of Nottingham School of Agriculture, \\ Sutton Bonington, Loughborough, Leicestershire
}

(Received 21st September 1971, accepted 14th October 1971)

\begin{abstract}
Summary. The presence of a male from the afternoon of pro-oestrus to the following morning resulted in significant increases in anterior pituitary and uterine weights both in female rats on an unrestricted food intake and in underfed females. A significant decrease in pituitary LH content was apparent in the underfed group exposed to males. A trend towards an increased number of ovulations was found in females of both groups subjected to the presence of a male when compared to control animals but the difference did not reach significance.
\end{abstract}

\section{INTRODUCTION}

Experiments by Cooper \& Haynes (1967) established that the oestrous cycle of the underfed rat is modified by the presence of the male, the lengthened and irregular cycles characteristic of underfeeding becoming similar to those of animals allowed unrestricted access to food. In view of the fact that copulation causes release of pituitary LH in female rats (Taleisnik, Caligaris \& Astrada, 1966), it was postulated that the effect might be due to the presence of a male which, in turn, caused removal of a nutrition-induced pituitary block in terms of gonadotrophin secretion. More recently, during an independent study, it appeared that the presence of the male rat may also affect the numbers of ovulations during an oestrous period since these were higher in a group of underfed rats which were mated compared to a group in which males were absent. No firm conclusions could be drawn from these results since the experiments were carried out at different times but it was tentatively suggested that factors associated with the presence of a male may influence ovulation by a similar mechanism to that by which it affects the oestrous cycle (Cooper, Haynes \& Lamming, 1970). The present study was designed to investigate this possibility.

\section{MATERIALS AND METHODS}

Sixty female rats of Wistar origin were used, together with males of the same strain and of proven fertility. They had been weaned at 21 days and fed a 
proprietary ration described by Cooper et al. (1970). Unrestricted access to water was given throughout. Animals were maintained in individual metal cages under a regimen of $12 \mathrm{hr}$ light/12 hr dark (light from 08.00 to 20.00 hours) and a controlled temperature of $21 \pm 2^{\circ} \mathrm{C}$. The experiment started when female rats were 14 weeks of age and had completed at least two normal oestrous cycles of 4 to 5 days (as determined by vaginal smears taken daily between 09.00 and 11.00 hours). Where mating was permitted, the male was introduced into the cage of the female at 12.00 hours on the afternoon of prooestrus and was removed the following morning whether or not mating had occurred. Ejaculation was detected by the presence of spermatozoa in the vaginal smear. If ejaculation had not occurred, the male was reintroduced at the next pro-oestrus in animals given unlimited access to food and after two cycles in underfed animals.

The rats were allocated at random to four groups: (a) ten animals were allowed unlimited access to food, (b) ten animals were fed similarly and allowed to mate, (c) twenty animals were given a restricted diet at 14.00 hours each day, consisting of $75 \%$ by weight of the mean daily unrestricted food intake, (d) twenty animals were treated similarly and allowed to mate. All animals in Groups (c) and (d) were fed the restricted ration for at least 28 days and animals in Groups (a) and (b) were kept for the same period before mating and/or autopsy. The animals were killed between 09.00 and 11.00 hours on the morning of metoestrus. The uterus and ovaries were removed and weighed and the number of corpora lutea determined by histological examination of the ovaries (Cooper et al., 1970). The pituitaries were removed, and after separation from the posterior lobes, the anterior pituitaries were weighed and stored at $-15^{\circ} \mathrm{C}$ for subsequent freeze-drying and assay. Quantitative assays for LH using a fourpoint design were carried out with pooled pituitaries from each treatment group by the ovarian ascorbic acid depletion assay as described by Schmidt-Elmendorff \& Loraine (1962). The log dose interval was $\log _{10} 5$. The doses of standard used were 0.8 and $4.0 \mu \mathrm{g}$ NIH-LH-s 14 and the doses of unknown were 0.5 and $2.5 \mathrm{mg}$ dried pituitary tissue.

Two animals from the full-fed group and four animals from the $75 \%$ group with males failed to mate and three animals from the $75 \%$ group with no males became acyclic. These animals are not included in statistical evaluations which were by analyses of variance.

\section{RESULTS}

The effect of male presence and dietary restriction on organ weight and pituitary LH content are shown in Table 1 . The effect of dietary restriction was to cause significant decreases in numbers of ovulations $(P<0.01)$, and ovary weight $(P<0.01)$, pituitary weight $(P<0.05)$ and uterine weight $(P<0.001)$ per $100 \mathrm{~g}$ body weight.

There were no significant alterations in numbers of ovulations associated with male presence at either feed level but a significant increase in uterine weight was found both at the unrestricted $(P<0.01)$ and restricted feed levels $(P<0.001)$. The effect of the male on the full-fed group was to increase the mean pituitary 
TABLE 1

THE EFFECT OF ASSOGIATION WITH THE MALE ON NUMBERS OF OVULATIONS, UTERUS, OVARY AND PITUITARY WEIGHTS AND PITUITARY LH CONTENT IN FEMALE RATS

\begin{tabular}{|c|c|c|c|c|}
\hline & \multicolumn{2}{|c|}{ Unrestricted feed } & \multicolumn{2}{|c|}{$75 \%$ feed } \\
\hline & No male & With male & No male & With male \\
\hline No. of animals & 10 & 8 & 17 & 16 \\
\hline $\begin{array}{l}\text { Mean body wt at slaughter } \\
(\mathrm{g} \pm \text { S.E. })\end{array}$ & $158 \cdot 9 \pm 3 \cdot 3$ & $160 \cdot 4 \pm 3 \cdot 0$ & $146 \cdot 4 \pm 2 \cdot 1$ & $146 \cdot 8 \pm 2 \cdot 1$ \\
\hline $\begin{array}{l}\text { Mean ovary wt }(\mathrm{mg} / 100 \mathrm{~g} \text { body } \\
\text { wt } \pm \text { S.E. })\end{array}$ & $39 \cdot 7 \pm 2 \cdot 0$ & $40 \cdot 1 \pm 2 \cdot 2$ & $32 \cdot 8 \pm 1 \cdot 5$ & $33 \cdot 9 \pm 1 \cdot 6$ \\
\hline $\begin{array}{l}\text { Mean uterus wt }(\mathrm{mg} / 100 \mathrm{~g} \text { body } \\
\text { wt } \pm \text { S.E.) }\end{array}$ & $138 \cdot 6 \pm 2 \cdot 6$ & $152 \cdot 3 \pm 3 \cdot 0$ & $80 \cdot 6 \pm 2 \cdot 0$ & $95 \cdot 3 \pm 2 \cdot 1$ \\
\hline Mean no. of ovulations \pm S.E. & $12 \cdot 4 \pm 0 \cdot 4$ & $12 \cdot 9 \pm 0 \cdot 5$ & $10 \cdot 9 \pm 0 \cdot 3$ & $11 \cdot 8 \pm 0 \cdot 4$ \\
\hline $\begin{array}{l}\text { Mean pituitary wet wt }(\mathrm{mg} / 100 \mathrm{~g} \\
\text { body wt } \pm \text { S.E.) }\end{array}$ & $6 \cdot 1 \pm 0 \cdot 2$ & $6 \cdot 9 \pm 0 \cdot 2$ & $4 \cdot 7 \pm 0 \cdot 2$ & $5 \cdot 9 \pm 0 \cdot 3$ \\
\hline $\begin{array}{l}\text { Mean total dry pituitary LH } \\
\text { content }(\mu \mathrm{g} \text { NIH-LH-S14) }\end{array}$ & $\begin{array}{c}8 \cdot 14 \\
(5 \cdot 5 \text { to } 12 \cdot 2)^{*}\end{array}$ & $\begin{array}{c}10 \cdot 74 \\
(7 \cdot 1 \text { to } 15 \cdot 5)\end{array}$ & $\begin{array}{c}6.73 \\
(4 \cdot 4 \text { to } 9 \cdot 7)\end{array}$ & $\begin{array}{c}3 \cdot 71 \\
(2 \cdot 2 \text { to } 5 \cdot 5)\end{array}$ \\
\hline Index of precision $(\lambda)$ & $0 \cdot 19$ & 0.19 & $0 \cdot 19$ & $0 \cdot 19$ \\
\hline
\end{tabular}

* Fiducial limits at $P=0.95$ in parentheses.

weight significantly $(P<0.01)$ but there was no change in pituitary LH content. In the underfed group, there was again a significant $(P<0.01)$ increase in mean pituitary weight associated with male presence, in this case accompanied by a significant $(P<0.05)$ lowering of pituitary LH content.

\section{DISCUSSION}

Since this work was undertaken, it has been reported that copulation causes significant increases in numbers of ova ovulated in the female rat. It was suggested that if the mating stimulus was properly timed, LH release may be reflexly affected in a normal spontaneous ovulator and the increases in ova produced may result from an additional release of $\mathrm{LH}$ acting on mature follicles which would not ordinarily ovulate (Rodgers, 1971). In the present study, there is a trend towards an increased number of ovulations as a result of the presence of a male. The difference approaches but does not reach significance. However, in the experiments described by Rodgers (1971) in which animals were allowed to mate at specified times, increases in numbers of ovulations occurred only in animals mating late, namely between 17.50 and 18.30 hours on the afternoon of pro-oestrus. Animals mating between 12.30 and 17.30 hours did not show an increase. In the present experiments, males were placed with females at 12.00 hours and were not removed until the following morning. No behavioural observations were made and no information on the time of mating is available. Since it can be assumed that a proportion of females would have mated before the critical time of 17.50 hours, the experiments were biased against obtaining significant increases in numbers of ovulations. The effect of the male on pituitary weight and uterus weight is, however, indicative that there exists a potential to increase the number of ova shed through an effect on 
gonadotrophin secretion as suggested by Rodgers (1971). This is substantiated by the significant decrease in pituitary LH content in underfed females ascribed to the presence of a male. The reason that no change occurs in pituitary LH potency in the group on unrestricted feed is in accord with findings that the copulation-induced fall in pituitary $\mathrm{LH}$ is transient and is not detectable $4 \mathrm{hr}$ after mating (Taleisnik et al., 1966). In the underfed group, the restricted food supply may have adversely affected the ability of the pituitary to synthesize LH and return to normal levels after a male-induced hormone release.

Rodgers (1971) states that coitus does not appear to cause increased oestrogen release from the ovary since there were no differences in uterine weights between groups containing a male, and control animals. The present study differs in that significantly increased uterine and pituitary weights were apparent in both underfed and full-fed animals in the presence of a male, indicating oestrogen involvement. Furthermore, physical contact between the sexes does not seem to be necessary since increases in uterine weight have been found when the sexes are separated by a wire-mesh barrier (Purvis, Cooper \& Haynes, 1971). The difference may again be one of time, the shorter contact period used by Rodgers being insufficient for oestrogen effects to become apparent.

These results, together with evidence that a short period of refeeding in underfed animals just before ovulation causes increases in numbers of ovulations (Cooper et al., 1970), suggest that stimuli of a relatively non-specific nature during oestrus may significantly affect ovulation. Furthermore, such effects may not be limited to this species. In the pig on low feed levels, for example, transient increases in feed level are also associated with pituitary LH changes and with increased numbers of corpora lutea. The increase in numbers of ovulations is variable, however, between experiments, often not reaching significance (Cooper, 1970). It may be that the degree of response to increased feeding in such experiments is confounded by other environmental factors such as the presence of a male and the time of mating.

\section{ACKNOWLEDGMENTS}

This work was carried out during tenure of a post-graduate research scholarship from the Meat and Livestock Commission which is gratefully acknowledged (K.J.G.).

\section{REFERENCES}

COOPER, K. J. (1970) The effect of restricted nutrient intake on fecundity in the pig and rat. Ph.D. thesis, University of Nottingham.

Cooper, K. J. \& Haynes, N. B. (1967) Modification of the oestrous cycle of the underfed rat associated with the presence of the male. F. Reprod. Fert. 14, 317.

Cooper, K. J., Haynes, N. B. \& Lamming, G. E. (1970) Effects of unrestricted feeding during oestrus on reproduction in the underfed female rat. F. Reprod. Fert. 22, 293.

Purvis, K., Cooper, K. J. \& Haynes, N. B. (1971) The influence of male proximity and dietary restriction on the oestrous cycle of the rat. 7. Reprod. Fert. 27, 167.

RoDgers, C. H. (1971) Influence of copulation on ovulation in the cycling rat. Endocrinology, 88, 433.

Schmidt-ElmendorfF, H. \& LoRAINe, J. A. (1962) Some observations on the ovarian ascorbic acid depletion method as a test for luteinizing hormone activity. 7 . Endocr. 23, 413.

TAleisnik, S., Galigaris, L. \& Astrada, J. J. (1966) Effect of copulation on the release of pituitary gonadotrophins in male and female rats. Endocrinology, 79, 49. 